Sign Systems Studies 29.1, 2001

\title{
Ecosemiotics and the sustainability transition
}

\author{
Max Oelschlaeger \\ McAllister Chair of Community, Culture, and Environment \\ Northern Arizona University, Flagstaff, Arizona, USA \\ e-mail: max.oelschlaeger@nau.edu
}

\begin{abstract}
The emerging epistemic community of ecosemioticians and the multidisciplinary field of inquiry known as ecosemiotics offer a radical and relevant approach to so-called global environmental crisis. There are no environmental fixes within the dominant code, since that code overdetermines the future, thereby perpetuating ecologically untenable cultural forms. The possibility of a sustainability transition (the attempt to overcome destitution and avoid ecocatastrophe) becomes real when mediated by and through ecosemiotics. In short, reflexive awareness of humankind's linguisticality is a necessary condition for transforming ecologically maladaptive cultural forms. As a multidisciplinary, interdisciplinary research program integrating the human and natural sciences, ecosemiotic inquiry closes the gap between biophysical ecology and human ecology. A provisional outline of a pragmatic theory of ecosemiotics attempts to describe the processes by which adaptive cultural changes might be facilitated and points toward substantive content areas that constitute sites for further research. Ecosemiotic inquiry frames cultural codes as these shape and reproduce the ongoing stream of individual and societal choices that shape distinctively human existence in a larger context of biophysical realities that drive natural selection. However, while ecosemiotics is a necessary condition for the sustainability transition, it is not a sufficient condition.
\end{abstract}

$$
\begin{array}{r}
1 . \\
\text { The matrix is everywhere ... } \\
\text { It is the world that has been pulled over } \\
\text { your eyes to blind you from the truth. } \\
\text { Morpheus, The Matrix }
\end{array}
$$

The emerging epistemic community of ecological semioticians (hereafter, ecosemioticians) and the multidisciplinary field of inquiry 
known as ecological semiotics (hereafter, ecosemiotics) offer a radical and relevant approach to what has been termed "the global environmental crisis". The term "radical" is warranted if for no other reason than the manifest failures of action taken within the existing rubric of scientific, technological, economic, and political rationality. "Rationality" itself is linguistically mediated, and therefore can only be comprehended from within language (Bernstein 1983; Lawson 1985; Toulmin 1958). The legitimating narratives that define rationality across economics and even the natural sciences are, from an ecosemiotic perspective, irrational (Wright 1992). The term "relevant" implies that ecosemiotics can "do work", that is, facilitate the sustainability transition - the simultaneous attempt to overcome destitution and to conserve the evolved planetary (biophysical) order (and thus avert ecocatastrophe) (Board on Sustainable Development 1999).

The ecosemiotic thesis as advanced below is twofold. First, that humankind qua human is a language animal. And second, that reflexive awareness (linguistically mediated self-consciousness) of humankind's linguisticality is a necessary condition for the transformation of ecologically maladaptive cultural forms (created through and encoded by language). The truth that drives the ecosemiotic thesis is that, whatever the illusions of The Matrix, cultural processes of selection (economic, political, philosophical, religious, and so on) are finally subject to natural selection (Cavalli-Sforza 2000; Ehrlich 2000). The risks of ignoring such a truth are enormous, if incalculable: mass extinction of species, global climate change, and the collapse of civilization. The opportunities created by affirming the ecosemiotic thesis are also enormous, but positive, that is culturally and naturally adaptive. (I gloss over crucial epistemic points here: as Putnam (1995: 12) argues, the truth works. "Since our claims get their substance from the roles they play in our lives, an account of truth will gain its substance from the accompanying account of how to get truth".)

Some may believe that such a claim is extreme. For one reason, the present forum offers the opportunity for an elliptical argument at best. A knock down argument is not possible. For another, the argument is rhetorically (architectonically and critically) directed at either the "already convinced" or those who are "leaning in the direction" of the ecosemiotic thesis. 
I begin with the obvious: humankind stands on the brink of multiple ecocatastrophes. These include an anthropogenic mass extinction event (Wilson 1992), anthropogenic climate change (Firor 1990), and runaway population growth. From an ecosemiotic perspective, such problems represent a pervasive disconnection between the dominant cultural codes and the natural, underlying systems upon which all cultures depend. Estimates are that at least fifteen million years would be required for the web of life to heal itself; that the consequences of climate change would fundamentally disrupt the world's food supply and political order; and that at best the planet can sustainably support approximately two billion people living somewhere between subsistence and consumerist lives.

Effectively these three facts constitute the hard realities of an evolutionary process that has within fifteen thousand years transformed the biophysical world from one to which the human species was loosely coupled (in a causal sense) to one where the human species is closely coupled (Allen, Hoekstra 1992; Firor 1990; Wilson 1992). Further, despite national and international efforts to take ameliorative actions, such as UNCED (1992) or the Kyoto Accord (1998), the rates of habitat destruction and species extinction continue to increase, the evidence of anthropogenic climatological perturbations continues to grow, and population (as well as consumption) continues to escalate. Clearly, the picture of the human estate painted here is gloomy, even neo-Malthusian ('neo' since technology is not ignored, as with Malthus, but indicted).

But there are mitigating realities. One is that since the middle of the Nineteenth Century, and especially in the last two or three decades, we have learned more about the sources of our humanity than in all previous history (Ehrlich 2000). Which is to say that the ecosemiotic thesis points toward a watershed event - a paradigm shift - in human self-comprehension. Far more has happened than can be detailed or even sketched here. Yet even a brief narrative must begin with the work of Charles Darwin, who intuited correctly that

the difference in mind between man and the higher animals, great as it is, certainly is one of degree and not of kind. [...] If it could be proved that certain high mental powers, such as the formation of general concepts, selfconsciousness \&c., were absolutely peculiar to man, which seems extremely doubtful, it is not improbable that these qualities are merely the incidental 
results of other highly-advanced intellectual faculties; and these again mainly the result of the continued use of a perfect language. (Darwin 1874: 106-107)

In effect, the specific difference between the human species and the other primates generally, and chimpanzees specifically, is grounded in the fact that we are language animals - Homo narrans. This point is affirmed by many, but consider D. Bickerton (1995), who argues that humankind is

not unique in most of the ways in which we have been made out to be. That is, we do not come equipped with wisdom, logic, vast cognitive powers, novel problem-solving capacities, immaterial minds, immortal souls, and all the other baggage that has been imputed to us at one time or another. We have language grafted onto a primate brain, and that's it. We are still animals, but this two-edged gift that has been laid upon us obliges us to live in ways no other animal could conceive of. (Bickerton 1995: 156)

Following in Darwin's wake, much has happened, with evolutionary biological studies, such as those of P. Lieberman (1984; 1998), who argues that a few biological changes explain the uniqueness of human linguistic and cognitive behavior; archeological-anthropological studies, such as those of R. Leakey (1992), who traces the natural history of the protohumanoids to species Homo sapiens through the coevolution of brain and language; anthropological-linguistic studies such as those of D. Bickerton (1990; 1995); and multidisciplinary, interdisciplinary human studies such as the work of L. L. CavalliSforza (2000; Cavalli-Sforza, Feldman 1981), T. Deacon (1998), and P. Ehrlich (2000).

I have touched on only a few of dozens of lines of inquiry, so my inferences and conjectures must be considered provisional. Then again, all truth claims are fallible. Two points are in order. One is that no credible understanding of humankind (generally, societally, or individually), from ' $A$ ' for anthropological to ' $Z$ ' for zoological, can sunder itself from biological reality, including the biological basis of language. And that said, no credible understanding of a cultural system - understanding by culture the accretion of information through language, that is, the culturgens or memes that direct human action within a cultural context - can therefore be sundered from biological underpinnings. Which is to say that, as we enter into the new millennium, ecosemiotics itself is rooted in biological soil.

Many have touched on this in a variety of ways. One is the philosopher, M. Merleau-Ponty (1968), who speaks of the awesome birth of vociferation, of the breath that, unlike the chirps and growls and 
bugles and sounds of all other creatures, becomes talk, of the talk that guides human action and becomes culture, of the culture that unintentionally becomes a plague upon the earth. But that is another story, elaborated in detail by many (Abram 1996).

More immediately relevant is the conjecture that the evolution, $a b$ initio, of cultural forms generally and political-economy specifically is driven by demographics, that is, human population growth (Johnson, Earle 1987). Jumping over fifteen thousand years of history, we come to the existing world order (which some have mistakenly characterized as the "New World Order": there's nothing new about something that has been thousands of years in the making). Try thinking of the existing world order - its legitimating narratives and political-economy, technologies and industries, factories and agricultural fields, systems of communication, transportation, and finance, hospitals and schools, and so on - as the outcome of a long process of cultural evolution. Even the world's poorest populations have some stake in the existing system, for without it, however inequitable and unjust, the end would soon come.

\section{3.}

Examined through the lens of ecosemiotics, the so-called global environmental crisis is a concatenation of unintended consequences. Human beings did not sit down around a collective table and intentionally decide to grow without limit, to convert the earth to one vast factory supporting themselves alone. No grand narrative was constructed to guide humans in the exploitation of the earth's biophysical systems with neither concern for future generations of humans nor care for the rest of the creatures. Rather humans in particular places and at particular times were making decisions and taking actions that enabled material survival and offered psychological meaning. Cultural schemes that gave individuals a sense of purpose and that provided adequate material sustenance endured. Those that failed simply collapsed - either in the short-run, through catastrophe (epidemics, famine), or in the long-run, through the inability to adapt to changed circumstances, such as soil salinization due to irrigated agriculture.

The evolution of political-economy, from band society to the urban-industrial state and the New World Order, has been biologically driven by the metabolic demands of ever-increasing numbers of hu- 
mans. Cultural systems survived by evolving ad seriatim the political, technological, and other schemes, including codes governing sexual reproduction, necessary for environmental exploitation and maintenance of the social order. The present world order sustains six billion people, in varying degrees of material comfort, political freedom, psychological well-being, and physical health. If the objective was to create a world order that exploits the environment for the purpose of sustaining six billion humans for some indeterminate but clearly limited period of time, then we have succeeded. Global environmental crisis was an unintended consequence.

The readers and author of this essay are fortunate to be counted among the twenty percent of the world's "haves", a population enjoying unprecedented levels of affluence and political freedom. We are the beneficiaries of the evolved cultural system. The "global middle class" is held culpable by some for human destitution and the global environmental crisis. Perhaps this charge has merit. More importantly, the world's haves arguably have the resources to facilitate the sustainability transition. There are at least two reasons why. One is that Agenda 21, the Kyoto Accord, and other conversations concerning the sustainability transition, such as the report of the Business Council for Sustainable Development (Schmidheiny 1990) and proposals for the reform of industrial capitalism (Hawken 1993; Hawken et al. 1999), are arguably the beginnings of an adaptive response. For the moment, however, they fail. Why?

Because these attempts to forge an alternative destiny are unconsciously entangled in a cultural narrative that separates human interests from the naturally evolved world. Such schemes are linguistically naive. For example, Agenda 21, in the parlance of ecosemiotics, perpetuates strong anthropocentrism, the privileging of ill-advised, narrow, and ecologically untenable human interests. Like the maps of the world drawn by Europeans c. 1400, Agenda 21 leaves the articulations that describe the terrain of a sustainable world marked as terra incognita. Critics, such as R. J. Johnston (1989) and N. Georgescu-Roegen (1971), have shown us the limited possibilities for reform inherent within the dominant discourses of political-economy and economics. The dominant narratives underlie the unintended consequences that threaten the future. Yet, even given its shortcomings and limits, at least Agenda 21 has started the conversation concerning sustainability. It needs time. Ecosemiotics can help.

Second, the so-called information revolution portends changes as radical in outcomes as the agricultural and industrial revolutions. Pes- 
simists believe that the "E-society", including genetic, nano, and robotic technology, is driving us in the wrong direction, threatening oblivion of the human species itself. Nature, on several accounts, is increasingly a simulacrum, a virtual reality. Thus the information revolution is the penultimate disconnection of culture and nature. Optimists argue the opposite thesis, claiming that new technologies, including the information revolution, will ensure ever greater abilities for economic development while simultaneously diminishing environmental impacts.

Ecosemioticians are more guarded, believing that the E-society is, indeed, a revolution in the communication and distribution of information. Facilitated through language, the replication of culture depends on the communication of information. But silicon-based, machine networks do not and can not make decisions about what culturally counts and what does not. Or what nature permits. Clearly, information and calculation are necessary for the sustainability transition. But information and calculation can also hasten humankind down the present path and/or even a worse path. Which underscores the importance of the ecosemiotic thesis. We are the only species capable of intentional (conscious) evolution. Yet we are overdetermined by the dominant paradigm that not only sustains us in the near-term, but creates the illusion of civilizational takeoff.

Much like the recent Concorde catastrophe, industrial culture is increasingly vulnerable to "minor mishaps", bifurcations that cascade into disaster. Like a mass extinction event. We are also capable of avoiding catastrophe, at least that of our own making. "In wildness is the preservation of the world", wrote the sage of Concord, Henry Thoreau, nearly 150 years ago. Conventionally read as a preservationist, Thoreau is better read as the first thinker to directly engage the question of deliberate cultural adaptation. Arguably, he is a proto-ecosemiotician (Oelschlaeger 1991).

Cultures constructively adapt their foundational narratives to the exigencies of existence. Or they die. Thoreau wondered how humankind might create stories that connect rather than separate us from earth. How might we reconnect human flourishing with evolved biophysical complexity? In large measure, of course, that is the task of the inclusive discursive community of scientists, corporate leaders, politicians, and many others. But ecosemioticians could and arguably should be the catalyst for such conversations. 


\section{4.}

Language bestowed on its possessor powers that yielded far more than mere survival, powers that effectively conferred on our species the stewardship of earth. Yet, formidable as these powers were, they carried within them the seeds of destruction. Language had given us, not enough, but too much: not just the stewardship of earth, but the capacity to destroy species weaker than ourselves, and even features of the environment on which our own survival might depend. Yet language is at the same time the nurturer and facilitator of all that is best in us, all that seeks to avoid such a fate and to bring us back into unity with the rest of creation.

(Bickerton 1990: 256)

Karl Marx among others observes that philosophers have long speculated about the world, forgetting that the most important task is to change it. If ecosemiotics is to be more than academic entertainment, then an outline is in order, however provisional or elliptical, of how the ecosemiotic thesis facilitates intentional cultural change. Any pragmatic ecosemiotics must at some point affect "ecosemiosis", that is, the overlap of human ecology and biophysical ecology, the chaotic interface of the body of culture and the body of nature. The divide of biophysical ecology or nature and human ecology or culture is not only intellectually untenable but also dangerous, threatening catastrophic and irreversible change in biophysical processes (Golley 1993). The dominant cultural codes - economics, politics, ethics, psychology, and so on - perpetuate that separation, thus leading the human species toward a fateful rendezvous with natural selection. A theory of ecosemiotics should describe the processes by which adaptive cultural changes might be facilitated.

Premises 1 through 10 below offer the beginnings of such a theory. The premises are stated elliptically, followed by a brief commentary. Premises 1-10 are intellectual "promissory notes" pointing toward substantive content areas that constitute sites for ongoing conversation, continuing earlier conversations articulated by and within various epistemic communities. K. Kull (1998: 348), for example, notes the potential for ecosemiotics to "become a large and important field of research with considerable practical applications". Premises 1-10 basically move from the general toward the particular, from the past to the present, and from theory to praxis (that is, problem driven prem- 
ises concerning social reconstruction). Finally, the theory of ecosemiotics should be thought of as roughly analogous to the theory of evolution and what has been called "Darwin's Century". Part of the genius of Charles Darwin was his ability to integrate multiple theories such as geology, paleontology, botany, and zoology - into a comprehensive theory, namely, evolution. Ecosemiotics awaits its Darwin. The author does not aspire to that role, but rather self-identifies as a minor prophet foretelling things to come. Rather than being driven by a single figure in the Cartesian tradition of solitary thinkers, the advance of ecosemiotics is better conceptualized in terms of distributed creativity.

P1. Following in Darwin's wake, the specific and crucial difference between the human species and our closest mammalian kin (chimpanzees, with whom we share more than 99 percent of our genetic makeup) is language. Language enables uniquely human culture. Evolution $\rightarrow$ Language $\rightarrow$ Culture

P2. The biological driver for the evolution of culture (e.g., political-economy, technology) is population. Population $\rightarrow$ Cultural Innovation

P3. Cultural forms are carried by memes (culturgens, ideas, stories) which are analogous to genes: memes are to the individuals who constitute the body of culture as genes are to the organisms that constitute the body of species. Language $\rightarrow$ Narratives/Ideologies $\rightarrow$ Body of Culture

P4. Memetic codes organize themselves into co-adapted complexes that guide the present and overdetermine the future. Cultural Past $\rightarrow$ Present $\rightarrow$ Overdetermined Future

P5. Just as genes define species, so memes define cultures. Just as genetic mutations determine adaptive fitness of organisms in environmental context, so memetic changes define the adaptive fitness of cultures. Memetic changes are typically overdetermined by the dominant codes; thus, "paradigm change" is exceedingly difficult. Intentional changes $\rightarrow$ Circumscribed by the Past $\rightarrow$ Unintended Future

P6. Ecosemiotics can mitigate cultural overdetermination, thus facilitating a "paradigm shift". Ecosemiotically Facilitated Change $\rightarrow$ Deliberate Future/Sustainability Transition

P7. There are two obvious ways to change cultural stories. One is to delegitimate the dominant code or important aspects (master memes) of that code. The other is to offer alternative symbolic structures. Delegitimation + Alternative Stories $\rightarrow$ Sustainability Transition 
P8. Myths are foundational (architectonic) stories; it follows that rapid societal change can be induced through mythic innovation and/or reconstruction. Mythic Alternatives (Foundational Stories) $\rightarrow$ Sustainability Transition

P9. Distributed creativity and inclusive political participation are vehicles for cultural transformation. Innovative Thinking + Policy Change $\rightarrow$ Sustainability Transition

P10. We are Homo narrans, storytelling culture-dwellers. Culture cannot be reinvented ex nihilo; yet ecosemiotics tells us that alternative, sustainable futures are possible. Homo narrans $\rightarrow$ Ecosemiotics $\rightarrow$ Alternative Futures

\section{5.}

... Language underlies and constitutes the very possibility of human social life, including knowledge, institutions, and social-natural interactions ... But if language characterizes and constitutes human beings, then the idea of language must be logically prior to the idea of being human, and both human beings and human society must be understood in terms of the active and organizing structure of language ...... For language to be effective ... [logically implies] that it can sustain its own possibility, that the organized use of language will sustain the possibility of human actions and social life, and thus the possibility of language.

(Wright 1992: 16)

At this juncture, seemingly, books and more books, conferences and more conferences, are required to flesh out the details of the ecosemiotic thesis. However, linguistic convention requires brevity. Simply put, the premises above converge on the notion that we are language animals (Darwin 1874; Taylor 1985). Homo narrans. Storytelling culture-dwellers. The so-called gene shortage problem alone definitively undercuts alternative hypotheses (Ehrlich 2000). The ecosemiotic thesis, regardless of the fallibility of the premises above, opens humankind to the possibility of conscious evolution, sometimes termed "meta-biological evolution".

Natural selection, working over tens of thousands of years, constituted the biological basis of language; with language came the move into distinctively human culture. Culture can be and has been defined in many ways, but at the heart of any viable account lies the notion 
that the essence of culture is the symbolic accrual of experiential learning (the school of hard knocks) and the subsequent transmission of these lessons within generations of humans as well as between succeeding generations. Such transmission is accomplished linguistically rather than genetically. L. L. Cavalli-Sforza's (2000; Cavalli-Sforza, Feldman 1981) work is unsurpassed in the study of genes, culture, and language. With language and the move into culture, humankind becomes what has sometimes been termed a "symbolic species" (Bickerton 1990). "Symbolic analysis is the basis for a remarkable new level of self-determination that human beings alone have stumbled upon" (Deacon 1998: 434).

Once the threshold was crossed from late Paleolithic hunting and gathering, characterized by band society, into early sedentarism - an event likely precipitated by a prehistoric food crisis, itself driven by the collapse of Pleistocene grassland ecosystems - the nature-culture interface was dramatically transformed, beginning with politicaleconomy. For Paleo-hunter-gatherers economic utility vanished at the margin of portability (Sahlins 1972). Today the converse is the case: the body of culture - with six billion human metabolisms - is insatiable. From an ecosemiotic perspective such an outcome is not mysterious, however complicated, since the so-called ecological transition from Paleolithic to Neolithic culture was facilitated and continuously mediated by language. We are caught up in that ongoing history of effects. One obvious way is evident in the fact that, as J. W. Bennett (1976: 140) notes, "There is no built-in mechanism restraining the human proclivity to use, and expand the use, of natural substances this has to be consciously developed under special circumstances". Cultural codes that eventuated in technologies and institutions supplying necessary and desired material goods endured; those codes failing the test were selected out.

However, the move into linguistically mediated culture did not and does not exempt humankind from the economy of nature. The epigraph at the start of this section (Wright) powerfully, if elliptically, drives home that point. (Although industrial capitalism and its associated ideologies present the appearance that the modern individual has escaped natural limits - excepting death - consumerism is "window dressing", that is, a distraction from our continuing situatedness in nature.) For cultural codes (memes, culturgens) - literally the instructions for the production and reproduction of the body of culture - are ultimately subject to natural selection. "Thus, each cultural decision must pass two levels of control: cultural selection acts first through 
choices made by individuals, followed by natural selection, which automatically evaluates these decisions based on their effects on our survival and reproduction" (Cavalli-Sforza 2000: 178).

However, there are some crucial differences between genes and biological evolution, and memes and cultural evolution. Cultural codes can be intentionally changed; genetic change is by mutation. Further, cultures (like species) endure over longer periods of time than individuals; thus, decisions made by individuals that favorably affect their own survival and reproduction in the short-term can have longterm consequences that adversely affect the sustainability of a culture. Finally, cultural codes profoundly affect the choices made by individuals. Some call this phenomenon the "preschematization of language".

With increasing urgency...we are led to ask....whether there may not be hidden in our experience of the world a primordial falsity; whether, in our linguistically transmitted experience, we may be prey to prejudices, or worse still, to necessities which have their source in the linguistic structuring of our first experience of the world and which would force us to run with open eyes, as it were, down a path whence there was no other issue than destruction. (Gadamer 1988: 491)

Thus, a focus for inquiry within the ecosemiotic community is on cultural codes as these shape and reproduce the ongoing stream of the choices that shape distinctively human existence in a larger context of biophysical realities that drive natural selection.

For example, technology is a vital area for ecosemiotic inquiry. "Techno-narratives" mediate the technological processes and institutions employed by a culture to enable the survival of human organisms. Donna Haraway's Modest Witness (1997) is arguably an ecosemiotic tour de force, surveying and apprising a comprehensive array of symbolic forms that constitute "the figuration" that constitutes and reconstitutes the technological body of culture. Whatever the unintended consequences of technology, civilization would collapse without the near-term continuation of present day technologies, regardless of long-term consequences. From the perspective of ecosemiotics, technological innovation must be involved in any sustainability transition. Just as clearly, as many have argued, the narrative of cultural progress as engendered by technology fails on multiple tests.

The dominant narratives of the New World Order (including techno-narratives) are legitimated by a powerful, interwoven mythic complex, termed "Cornucopianism". The ideas of progress - 
roughly, that the human future will be better than the past, especially as measured by economic success, that is, the conversion of natural resources into needed and desired material goods - and technological control - roughly, that through applied science the human species has the means to achieve the aforementioned progress - constitute the heart of Cornucopianism. They are, in a phrase, foundational myths.

If we think of myths as architectonic forms, as rhetorical structures that undergird the basic woof and warp of society, then K. Burke's (1950) sage reflections help us understand how and why Cornucopianism rules.

For [architectonic] rhetoric is not rooted in any past condition of human society. It is rooted in an essential function of language itself, a function that is wholly realistic, and is continually born anew; the use of language as a symbolic means of inducing cooperation in beings that by nature respond to symbols. (Burke 1950: 43)

If this is the case, the present efforts of those who would reconstruct the world - for example, so-called Agenda 21, the New World Order - are to no avail. Why? Because such efforts are ecosemiotically naive. The possibility of intentionally making the sustainability transition (i.e., conscious evolution) implies - a necessary but not sufficient condition - a linguistically mediated awareness of the basic codes/meme complexes that overdetermine the body of culture and the ability to use "the tools of language". Criticism. Delegitimation. Poetry. Myth. Parable. Mythopoesis. Rhetoric. Communication.

\section{6.}

If sufficiently successful, and mankind escapes the dark abysses of its own making, then truly will the future belong to man[kind], the only product of biological evolution capable of controlling its own further destiny.

(Handler 1970: 888)

The epigraph at the beginning of this essay (from the film The Matrix) turns on sophisticated insights into the nature of human reality. We live in worlds hung on the loom of language, that is, the stories that provide the woof and warp through which the shuttle of our individual and collective lives passes back and forth. Yet the weaving of the fab- 
ric of culture remains opaque to those who cannot affirm the ecosemiotic thesis, for consciousness remains tightly bound within the matrix of daily life.

Consider two examples of the matrix that blinds us from the truth. Recall The Wizard of $\mathrm{Oz}$, and the scene where Dorothy's dog, Toto, pulls back the curtain hiding a short, pudgy man who has been manipulating a device that controls the movements and voice of a fearsome apparition - The Wizard of $\mathrm{Oz}$. The instant the curtain is pulled back, the game is up. Oz is no longer the Wizard, but only a human who, as it turns out, still provides useful help to the Dorothy and her confreres. Almost everyone, even children, "gets it", that is, the exposure of the Wizard as a fraud.

The other matrix that blinds us from the truth can be illustrated simply by ecosemiotically reconsidering the term "global environmental crisis". The world historic project that is industrial capitalism - the so-called New World Order - linguistically legitimates such a notion. But the ever increasing prospect of mass extinction of species, global climate change, and explosive population growth confirms the irrelevance of such a notion. For global environmental crisis is itself part of a matrix that pulls the symbolic wool over our eyes.

Global environmental crisis is in truth a crisis of language, which is to say a human crisis, a dark abyss of our own making. N. Evernden (1985) points out the irony that self-identified environmentalists fail to realize "the very entity they defend - environment — is itself an offspring of the nihilistic behemoth they challenge. It [including terms like "global environmental crisis"] is a manifestation of the way we view the world". The matrix lives. Ecosemiotically redescribed "we are not in an environmental crisis, but are the environmental crisis" (Evernden 1985: 134).

Which is to say that if it is through language that we have been disconnected from nature, then reconciliation must also be effected through language. But self-conscious awareness of the reality of language is a necessary condition for such a reconciliation. Just as Columbus's voyage to the so-called new world refuted the flat earth hypothesis, or just as heliocentric ideas dismantled geocentrism, or just as the evolutionary hypothesis played havoc with supernaturalism, so ecological semiotics radically challenges conventional ideas concerning humanity and/or culture. There are no fixes for "global environmental crisis" within the dominant code, only tinkering and more of the same. The possibility of a sustainability transition becomes actual when mediated by and through ecosemiotics. 
Yet clearly the ecosemiotic thesis itself must be tempered. J. Kristeva's (1989) insights into "language, the unknown", are relevant, for there is no specifically human place outside language from which to explain language, to know language, to use language. "Method" and "discipline" are social and linguistic artifices that deceive the linguistically naive. The ecosemiotic thesis, as discussed here, is not a sufficient condition for the sustainability transition. But it is arguably a necessary condition, one that reveals more than it conceals. For without the conscious ability to escape the overdetermination of the past, the future will bring biocultural catastrophe.

\section{References}

Abram, David 1996. The Spell of the Sensuous: Perception and Language in a More-than-Human World. New York: Pantheon.

Allen, Timothy F. H.; Hoekstra, Thomas W. 1992. Toward a Unified Ecology. New York: Columbia University Press.

Bennett, John W. 1976. The Ecological Transition: Cultural Anthropology and Human Adaptation. New York: Pergamon Press.

Bernstein, Richard J. 1983. Beyond Objectivism and Relativism: Science, Hermeneutics, and Praxis. Philadelphia: University of Pennsylvania Press.

Bickerton, Derek 1990. Language and Species. Chicago: University of Chicago Press.

- 1995. Language and Human Behavior. Seattle: University of Washington Press.

Board on Sustainable Development, Policy Division, National Research Council 1999. Our Common Journey: A Transition Toward Sustainability. Washington, D.C.: National Academy Press.

Burke, Kenneth 1950. A Rhetoric of Motives. Berkeley: University of California Press.

Cavalli-Sforza, Luigi Luca 2000. Genes, Peoples, and Language. Translated by Mark Seielstad. New York: North Point Press.

- and M. W. Feldman 1981. Cultural Transmission and Evolution: A Quantitative Approach. Princeton: Princeton University Press.

Darwin, Charles 1874 [1871]. The Descent of Man, and Selection in Relation to Sex. 2nd ed. London: John Murray.

Deacon, Terrence W. 1998. The Symbolic Species: The Co-Evolution of Language and the Brain. New York: W. W. Norton.

Ehrlich, Paul R. 2000. Human Natures: Genes, Cultures, and the Human Prospect. Washington, D.C.: Island Press.

Evernden, Neil 1985. The Natural Alien: Humankind and Environment. Toronto: University of Toronto Press.

Firor, John 1990. The Changing Atmosphere: A Global Challenge. New Haven: Yale University Press. 


\section{Max Oelschlaeger}

Gadamer, Hans-Georg 1988. Truth and Method. Translated by Garrett Barden and John Cumming. New York: Crossroad Publishing.

Georgescu-Roegen, Nicholas 1971. The Entropy Law and the Economic Process. Cambridge: Harvard University Press.

Golley, Frank B. 1993. A History of the Ecosystem Concept in Ecology: More than the Sum of the Parts. New Haven: Yale University Press.

Handler, Philip (ed.) 1970. Biology and the Future of Man. London: Oxford University Press.

Haraway, Donna J. 1997. Modest_Witness@Second_Millennium: FemaleMan $^{\mathrm{C}}$ Meets_OncoMouse $\mathrm{T}^{\mathrm{TM}}$. London: Routledge.

Hawken, Paul 1993. The Ecology of Commerce. New York: Harper Collins.

Hawken, Paul; Lovins, Amory; Lovins, L. Hunter 1999. Natural Capitalism: Creating the Next Industrial Revolution. Boston: Little, Brown \& Co.

Johnson, Allen W.; Earle, Timothy 1987. The Evolution of Human Societies: From Foraging Group to Agrarian State. Stanford: Stanford University Press.

Johnston, R. J. 1989. Environmental Problems: Nature, Economy, and State. London: Belhaven Press.

Kristeva, Julia 1989. Language the Unknown: An Invitation into Linguistics. Translated by Anne M. Menke. New York: Columbia University Press.

Kull, Kalevi 1998. Semiotic ecology: Different natures in the semiosphere. Sign Systems Studies 26: 344-369.

Lawson, Hilary 1985. Reflexivity: The Postmodern Predicament. LaSalle: Open Court.

Leakey, Richard E.; Roger Lewin 1992. Origins Reconsidered: In Search of What Makes Us Human. New York: Doubleday.

Lieberman, Philip 1984. The Biology and Evolution of Language. Cambridge: Harvard University Press.

- 1998. Eve Spoke: Human Language and Human Evolution. New York: W. W. Norton.

Merleau-Ponty, Maurice 1968. The Visible and the Invisible. Translated by Alphonso Lingis. Evanston: Northwestern University Press.

Oelschlaeger, Max 1991. The Idea of Wilderness: From Prehistory to the Age of Ecology. New Haven: Yale University Press.

Putnam, Hilary 1995. Pragmatism: An Open Question. Cambridge, Mass: Blackwell.

Sahlins, Marshall 1972. Stone-Age Economics. New York: Aldine de Gruyter.

Schmidheiny, Stephen 1990. Changing Course: Report of the World Business Council on Sustainable Development. Cambridge: MIT Press.

Taylor, Charles 1985. Human Agency and Language: Philosophical Papers 1. Cambridge: Cambridge University Press.

Toulmin, Stephen Edelston 1958. The Uses of Argument. Cambridge: Cambridge University Press.

Wilson, Edward O. 1992. The Diversity of Life. Cambridge: The Belknap Press of Harvard University Press.

Wright, Will 1992. Wild Knowledge: Science, Language, and Social Life in a Fragile Environment. Minneapolis: University of Minnesota Press. 


\section{Экосемиотика и переход на Экономное сушествование}

Формируюшаяся эпистемологическая общность экосемиотиков и мультидисциплинарная область исследования, называемая экосемиотикой, предлагают радикальный подход к так называемому глобальному кризису окружающей среды. Доминантный код не отражает проблемы окружающей среды и, закрепляя экологически несостоятельные формы культуры, этот код определяет и (наше) будущее. Посредством экосемиотики может быть реализована возможность перехода к экономичному способу существования (справляясь $\mathrm{c}$ дефицитом ресурсов и предотврашая экокатастрофу). Иными словами, знание лингвистической зависимости человечества является необходимым условием для изменения экологически плохо приспособившихся форм культуры. В качестве мульти- и интердисциплинарной исследовательской программы, объединяющей гуманитарные и естественные науки, экосемиотический подход заполняет пробел между биофизической экологией и экологией человека. Предварительная теория экосемиотической практики стремится описать процессы, с помощью которых можно облегчить приспособленческие культурные изменения, и указывает на существенные области, могушие стать полями дальнейшего исследования. Экосемиотика изучает коды культуры, так как именно они офрмляюо и репродуцируют беспрерывный поток индивидуальных и общественных выборов. Эти выборы характеризуют и создают специфику человеческого существования в более широком контексте биофизической действительности, которая наптавляет естественный отбор. Хотя экосемиотика и является необходимым условием для перехода к экономичному существованию, это не достаточное условие.

\section{Ökosemiootika ja üleminek säästlikule eluviisile}

Kujunev ökosemiootikute episteemiline kogukond ja ökosemiootikaks nimetatud multidistsiplinaarne uurimisvaldkond pakuvad radikaalset ja asjakohast lähenemist niinimetatud globaalsele keskkonnakriisile. Dominantne kood ei kajasta keskkonnaprobleeme ning põlistades ökoloogiliselt ebakohased kultuurilised vormid määrab see kood ka (meie) tuleviku. Ökosemiootika poolt vahendatuna võib realiseeruda võimalus üle minna säästlikule eluviisile (ületades puuduse ja vältides ökokatastroofi). Lühidalt öeldes on teadlikolu inimkonna keelesõltuvusest vajalik tingimus ökoloogiliselt halvasti kohastunud kultuuriliste vormide muutmiseks. Multi- ja interdistsiplinaarse humanitaarja loodusteadusi ühendava uurimisprogrammina täidab ökosemiootiline lähenemine tühimiku biofüüsikalise ökoloogia ja inimökoloogia vahel. Öko- 
semiootilise praktika esialgne teooria püüab kirjeldada protsesse, mille abil hõlbustada kohastumuslikke kultuurilisi muudatusi, ja osutab sisuliselt olulistele valdkondadele, millest võiksid kujuneda edasise uurimise alad. Ökosemiootika uurib kultuurikoode, kuna need kujundavad ja reprodutseerivad individuaalsete ja ühiskondlike valikute katkematut voolu. Need valikud iseloomustavad ja kujundavad inimeksistentsi eripära laiemas biofüüsikalise tegelikkuse kontekstis, mis suunab looduslikku valikut. Kuigi ökosemiootika on vajalik tingimus säästlikule eluviisile üleminekuks, ei ole see piisav tingimus. 